\title{
Formulation and Commercialization of Rhizobia: Asian Scenario
}

\author{
Rajendran Vijayabharathi, Arumugam Sathya, \\ and Subramaniam Gopalakrishnan
}

\begin{abstract}
The symbiotic agreement of rhizobia with leguminous plants is making a valuable contribution to agriculture primarily as nitrogen fixers and secondarily as plant growth promoters by their key role as phosphate solubilizers, growth hormone producers, abiotic and biotic stress relievers, and host-plant resistance enhancer. In the so far identified 14 genera and 105 species of rhizobia, a huge number of research reports were reported in various aspects. Genetically modified rhizobia with desirable traits have also been surfed to a large extent. Besides their potentiality, the commercial success of rhizobia as a bio-inoculant is poor, because most of the inoculants produced worldwide are of poor or suboptimal quality. Though voluminous data and better understanding are available on various formulation technologies, longevity and efficacy of the final product are loosed at the farmer's end. This book chapter is focused to address various types of formulations applicable to rhizobia, quality control for longevity, gaps in knowledge on bringing the native potential of rhizobia during formulation, and critical control points to be considered during its development. The chapter also shares ICRISAT's experience in its rhizobial collection, formulation developments, and efficacy testing.
\end{abstract}

\section{Keywords}

Rhizobia $\bullet$ Legumes $\bullet$ Asia $\bullet$ Formulations $\bullet$ Peat $\bullet$ Legislations

\footnotetext{
R. Vijayabharathi $\bullet$ A. Sathya $\bullet$ S. Gopalakrishnan $(\bowtie)$

International Crops Research Institute for the Semi-Arid Tropics (ICRISAT),

Patancheru, 502324 Hyderabad, Telangana, India

e-mail: s.gopalakrishnan@cgiar.org
} 


\subsection{Introduction}

Approximately $80 \%$ of the human dietary nitrogen needs, i.e., $24 \mathrm{Tg} / \mathrm{year}$ in tropics and subtropics, are satisfied by the plants. But with the increasing earth's population at a rate of $1.4 \%$ annually, the present scenario of crop production rates will not be sufficient to maintain the dietary needs (Mannion 1998; Fink et al. 1999). Deterioration of agricultural lands and use of marginal lands for crop production are further complicating the scenario, because soil $\mathrm{N}$ management plays a critical role in crop yield (Huang and Rozelle 1995; Bramley et al. 1996; Rozelle et al. 1997; Savant et al. 1997). While considering the past scenario, i.e., between 1950 and 1990, $\mathrm{N}$ fertilizers played a major role in increasing the cereal grain yield. They yielded 6-9 mg grain/hand take-up 200-300 kg N ha year ${ }^{-1}$ (Vance 1998). Still the use of $\mathrm{N}$ fertilizers at global scale is in increasing trend as per the FAOSTAT data. Though nitrogen fertilizers gave an increase in crop production, there was a great impact in the environment which includes NOx loss, acid rain, higher leaching, change in the global $\mathrm{N}$ cycle, and polluted ground water. When developed countries were facing such problems, developing countries were affected by the additional issues of fertilizer cost, availability, and distribution problems (Kinzig and Socolow 1995; Vitousek et al. 1997).

In the context of sustainable $\mathrm{N}$ management, symbiotic nitrogen fixation (SNF) plays a vital role. Though it represents systems including either rhizobia, Azolla, or Anabaena with either leguminous or cereal crops, the system of legume-rhizobia symbiosis is the critical factor as it involved in $80 \%$ (approximately 100$122 \mathrm{Tg} \mathrm{year}^{-1}$ ) of biologically fixed nitrogen by involving a range of species such as Rhizobium, Bradyrhizobium, Sinorhizobium, Azorhizobium, Mesorhizobium, and Allorhizobium (Vance 1998; Herridge et al. 2008). The process of nitrogen fixation through SNF was reviewed periodically at various aspects covering biochemical and molecular mechanisms and genetic factors (Jiao et al. 2016; Remigi et al. 2016). When considering the fixed nitrogen effect by fertilizer and SNF, two key factors have to be considered: (i) fixed N by SNF is less susceptible to volatilization, leaching, or denitrification than fertilizer $\mathrm{N}$, and (ii) industrial production of $\mathrm{N}$ requires approximately $1.5 \mathrm{Kg}$ oil $\mathrm{Kg}^{-1}$ fertilizer in order to reduce $\mathrm{N}$ to ammonia along with the requirement of high temperature and pressure. Though SNF is also an energydemanding process involving 16-24 moles of ATP for reducing 1 mole of dinitrogen, its persistence, stability, and absence of post-fixation effects add positive impact over fertilizer N. As per the review by Herridge et al. (2008), symbiosis by rhizobia is the efficient system for SNF as it contributes $55,140 \mathrm{~kg} \mathrm{~N} \mathrm{ha}^{-1}$, whereas $0.330 \mathrm{~kg} \mathrm{~N} \mathrm{ha}^{-1}$ is by other biological systems. The symbiosis by cyanobacteria contributes for $5 \mathrm{Tg} \mathrm{N}$, whereas by free-living, associative, and endophytic bacteria provides 10-20 Tg N. Actinorhizal symbiosis estimates about 4-42 g N tree ${ }^{-1}$ (Dommergues 1995), and cycads contribute $8-19 \mathrm{~kg} \mathrm{~N} \mathrm{~h}^{-1}$ in a year (Vessey et al. 2004).

Rhizobia, the efficient nitrogen fixer, are a term used for collective bacteria that enters symbiosis with legumes. Initially, till 1982, it was considered that Rhizobium is the only bacteria that possess these properties, but today, it was identified that there are 14 genera in two subphyla of Proteobacteria, viz., $\alpha$-Proteobacteria and 
$\beta$-Proteobacteria. $\alpha$-Proteobacteria includes the genera Agrobacterium, Allorhizobium, Azorhizobium, Bradyrhizobium, Devosia, Mesorhizobium, Methylobacterium, Ochrobactrum, Phyllobacterium, Rhizobium, Shinella, and Sinorhizobium (syn. Ensifer), and $\beta$-Proteobacteria includes Burkholderia, Cupriavidus, and Herbaspirillum. The number of genera in the rhizobia list is increasing day by day by various studies. This increasing number of rhizobia isolation led to reclassification and redesignation of some species (Lindström et al. 2010).

Development of such rhizobia as inoculants for legume crops is the most valuable contributions ever made by science to agriculture since it is evident to reduce $\mathrm{N}$ fertilizer use. Initial studies of inoculation were performed at a very basic level and laborious moving of soil from fields of well-nodulated legumes to legume-free fields (Fred et al. 1932). European countries initiated the inoculums development by advising their farmers to treat legume seeds with glue and sieved air-dried soil from well-nodulated plants (Walley et al. 2004). The work of Hellriegel and Beijerinck in the 1880s has brought a record on using pure cultures of rhizobia on inoculation of legume seeds. Within a couple of years, rhizobia were available in the European market for a range of species, and still it is getting developed involving new technologies (Guthrie 1896; Perret et al. 2000). But in the context of Asian countries, still the legume inoculant technology is underdeveloped due to a range of factors. Hence, this book chapter is focused to discuss the factors affecting rhizobia inoculant development in Asia.

\subsection{Beneficial Traits of Rhizobia}

Rhizobia are primarily considered for nitrogen fixation. Still the research on SNF in relation to rhizobia is ongoing including genetically modified rhizobia (Lindström and Mousavi 2010; Okazaki et al. 2016). After the concept of plant growthpromoting rhizobacteria by Kloepper, rhizobia have also been surfed to a large extent for its plant growth-promoting (PGP) properties (Kloepper and Schroth 1978). Hence, a developed rhizobial inoculum will provide additional plant and soil health benefits besides fixing nitrogen. PGP properties of rhizobia have been reviewed previously by Gopalakrishnan et al. (2014) and Naveed et al. (2015). The representatives of rhizobia with PGP traits have been given here.

\subsubsection{Rhizobia as Phosphate Solubilizers}

Rhizobia including Rhizobium leguminosarum, Rhizobium meliloti, Mesorhizobium mediterraneum, Bradyrhizobium sp., and Bradyrhizobium japonicum (Vessey 2003; Afzal and Bano 2008) are the potential P solubilizers. The solubilization was aided by low molecular organic acids produced by them, for instance, 2-ketogluconic acid production by $R$. leguminosarum (Halder et al. 1990) and $R$. meliloti (Halder and Chakrabarty 1993). Enhanced growth in chickpea and barley plants by P-solubilizing rhizobia M. mediterraneum has been demonstrated by Peix et al. (2001). 


\subsubsection{Rhizobia as Iron Mobilizers}

Iron exists as insoluble hydroxides and oxyhydroxides which cannot be accessed by both plant and microbes. Some bacteria synthesize low molecular weight compounds termed as siderophores which are capable of sequestering $\mathrm{Fe}^{3+}$. Many rhizobia species including $R$. meliloti, Rhizobium tropici, $R$. leguminosarum, Sinorhizobium meliloti, and Bradyrhizobium sp. are reported to be potent siderophore producers (Arora et al. 2001; Carson et al. 2000).

\subsubsection{Phytohormone Production of Rhizobia}

Phytohormones are the essential substances for plant growth stimulation. They include indole-3-acetic acid (IAA), cytokinin, and gibberellins. IAA is the foremost phytohormone and plays a role in cell division and differentiation and also in nodule formation. Rhizobia strains are also reported to produce IAA via indole-3-pyruvic acid and indole-3-acetaldehyde pathway (Camerini et al. 2008). Similarly rhizobia have been reported to produce cytokinins which are involved in root development and root hair formation (Senthilkumar et al. 2009). Gibberellins which are responsible for stem elongation and leaf expansion are also reported in Rhizobium (Boiero et al. 2007). Some reports are there for production of abscisic acid which stimulates stomatal closure, induces seeds to store proteins, and induces gene transcription for protease inhibitors (Dobbelaere et al. 2003).

\subsubsection{Rhizobia as Biocontrol Agents}

Biocontrol properties have been demonstrated in several rhizobia strains through the mechanisms like competition for nutrients (Arora et al. 2001), production inhibitory substances including antibiotics (Chandra et al. 2007), production of hydrolytic enzymes (Ozkoc and Deliveli 2001), siderophores (Carson et al. 2000; Deshwal et al. 2003), and low molecular weight metabolites (Bhattacharyya and Jha 2012). Phytopathogens such as Rhizoctonia solani, Macrophomina phaseolina, and Fusarium solani were found to be controlled by rhizobia.

\subsubsection{Rhizobia as Abiotic Stress Relievers}

The stress of the plant depends on host-plant reaction which can be influenced by rhizobia and the symbiosis (Yang et al. 2009). Several reviews periodically documented the stress tolerance of Rhizobium and Bradyrhizobium against soil salinity, acidity, alkalinity, osmotic stress, and temperature fluctuations (Graham 1992; Kulkarni and Nautiyal 2000; Grover et al 2010). 


\subsection{Development of Rhizobia Formulations}

Development of an inoculant technology for microbes is a time-consuming and cumbersome process as it faces various issues because many of the microbes produce fruitful laboratory results but fail to reflect similar effects under field conditions. So the success of an inoculant depends on its optimal results in situ and sophisticated use including cost-benefit ratio by end user (Xavier et al. 2004). In the context of inoculant development, carrier, a vehicle which transfers the microbes from laboratory to field, plays a crucial role. An ideal carrier should provide a beneficial microenvironment for the inoculated microbes against a range of biotic and abiotic stress factors including contaminants, soil antagonists, soil health deterioration, temperature, dryness, UV light, and mechanical stress. It should include the features such as (1) sustained availability, (2) low cost, (3) high moisture absorption capacity, (4) easy to process, (5) easy to sterilize, and (6) buffering capacity (Keyser et al. 1993). An overview on the available carrier materials and different types of inoculants is given in Fig. 3.1. Each carrier and formulation technology has its own pros and cons; and several reviews summarizing the same are available (Jung et al. 1982; Van Elsas and Heijnen 1990; Daza et al. 2000; Catroux et al. 2001; Amarger et al. 2001; Deaker et al. 2004; Bashan et al. 2014; Nehra and Choudhary 2015; Gopalakrishnan et al. 2016). Different rhizobial formulations tested on various crops are summarized in Table 3.1.

America, Europe, and Australia have potential market for rhizobia and have well-developed inoculant technologies. It is estimated that, in Australia, legumes

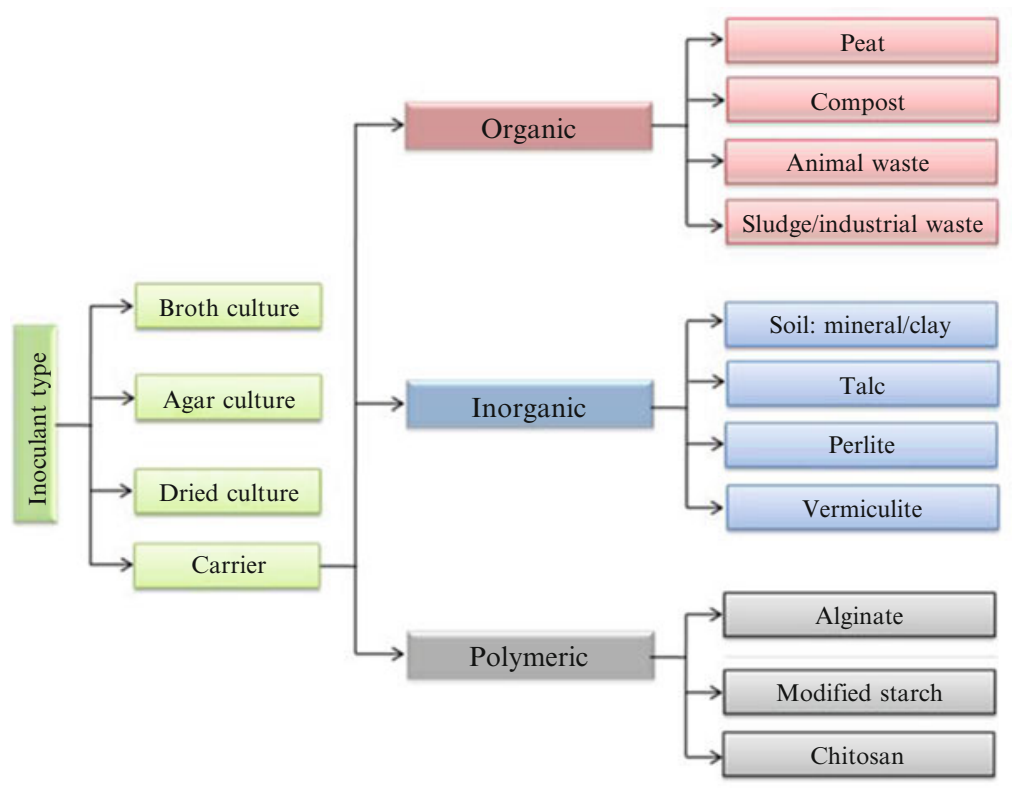

Fig. 3.1 Overview of inoculant types 
Table 3.1 Different formulations of rhizobia tested at field levels

\begin{tabular}{|c|c|c|c|c|}
\hline Formulation types & $\begin{array}{l}\text { Additive/ } \\
\text { treatment }\end{array}$ & Rhizobia & Crop tested & References \\
\hline \multirow[t]{4}{*}{$\begin{array}{l}\text { Liquid (culture } \\
\text { media or water) }\end{array}$} & $\begin{array}{l}\text { Glycerol, PVP, } \\
\text { trehalose, } \\
\text { FeEDTA }\end{array}$ & B. japonicum & Soybean & $\begin{array}{l}\text { Singleton et al. } \\
(2002)\end{array}$ \\
\hline & PVP; FeEDTA & $\begin{array}{l}\text { Several } \\
\text { rhizobia; } B . \\
\text { japonicum }\end{array}$ & Soybean & $\begin{array}{l}\text { Albareda et al. } \\
(2008)\end{array}$ \\
\hline & $\begin{array}{l}\text { Unknown } \\
\text { (commercial) }\end{array}$ & B. japonicum & Soybean & $\begin{array}{l}\text { Maurice et al. } \\
(2001)\end{array}$ \\
\hline & Gum Arabic & $\begin{array}{l}\text { Bradyrhizobium } \\
\text { sp., Rhizobium } \\
\text { sp. }\end{array}$ & $\begin{array}{l}\text { Acacia } \\
\text { mangium, green } \\
\text { gram, Leucaena } \\
\text { leucocephala }\end{array}$ & $\begin{array}{l}\text { Diouf et al. } \\
(2003) ; \text { Wani } \\
\text { et al. (2007) }\end{array}$ \\
\hline $\begin{array}{l}\text { Lyophilized } \\
\text { cells }\end{array}$ & $\begin{array}{l}\text { Soybean oil/ } \\
\text { peanut oil }\end{array}$ & Rhizobium sp. & $\begin{array}{l}\text { Bean, cowpea, } \\
\text { peanut }\end{array}$ & $\begin{array}{l}\text { Kremer and } \\
\text { Peterson (1983) }\end{array}$ \\
\hline \multicolumn{5}{|l|}{ Organic carrier } \\
\hline \multirow[t]{2}{*}{ Peat } & $\begin{array}{l}\text { None or with } \\
\text { undisclosed } \\
\text { additives }\end{array}$ & $\begin{array}{l}\text { B. japonicum; } \\
\text { Rhizobium sp., } \\
R . \\
\text { leguminosarum } \\
\text { bv. viciae }\end{array}$ & $\begin{array}{l}\text { Chickpea; faba } \\
\text { beans; maize; } \\
\text { pea; soybean; } \\
\text { wheat }\end{array}$ & $\begin{array}{l}\text { Clayton et al. } \\
(2004 a, b), \\
\text { Hamaoui et al. } \\
(2001), \text { Hungria } \\
\text { et al. (2010), } \\
\text { Hynes et al. } \\
(2001), \text { Khalid } \\
\text { et al. (2004), and } \\
\text { Revellin et al. } \\
(2000)\end{array}$ \\
\hline & Gum Arabic & $\begin{array}{l}\text { Rhizobium, } \\
\text { Bradyrhizobium }\end{array}$ & $\begin{array}{l}\text { Bean, Lupinus, } \\
\text { Hedysarum } \\
\text { Soybean }\end{array}$ & $\begin{array}{l}\text { Albareda et al. } \\
(2009) \text { and } \\
\text { Temprano et al. } \\
(2002)\end{array}$ \\
\hline $\begin{array}{l}\text { Coir dust/coco } \\
\text { peat }\end{array}$ & None & $\begin{array}{l}\text { Azorhizobium } \\
\text { caulinodans }\end{array}$ & Rice & $\begin{array}{l}\text { Van } \\
\text { Nieuwenhove } \\
\text { et al. (2000) }\end{array}$ \\
\hline $\begin{array}{l}\text { Vermicompost/ } \\
\text { earthworm } \\
\text { compost }\end{array}$ & Lignite & $\begin{array}{l}R . \\
\text { leguminosarum }\end{array}$ & Not tested & $\begin{array}{l}\text { Raja Sekar and } \\
\text { Karmegam } \\
(2010)\end{array}$ \\
\hline Sawdust & $\begin{array}{l}\text { Composted by } \\
\text { inoculation with } \\
\text { Cephalosporium } \\
\text { sp. and } \\
\text { Azospirillum } \\
\text { brasilense }\end{array}$ & $\begin{array}{l}\text { B. japonicum, } R \text {. } \\
\text { meliloti }\end{array}$ & $\begin{array}{l}\text { Groundnuts, } \\
\text { lucerne, and } \\
\text { grass mixture of } \\
\text { bird's foot } \\
\text { trefoil and } \\
\text { ryegrass; } \\
\text { soybean }\end{array}$ & $\begin{array}{l}\text { Kostov and } \\
\text { Lynch (1998) }\end{array}$ \\
\hline Sawdust & None & $\begin{array}{l}R . \\
\text { leguminosarum }\end{array}$ & Trifolium repens & $\begin{array}{l}\text { Arora et al. } \\
(2008)\end{array}$ \\
\hline
\end{tabular}


Table 3.1 (continued)

\begin{tabular}{|c|c|c|c|c|}
\hline Formulation types & $\begin{array}{l}\text { Additive/ } \\
\text { treatment }\end{array}$ & Rhizobia & Crop tested & References \\
\hline $\begin{array}{l}\text { Grape bagasse, } \\
\text { cork compost }\end{array}$ & $\begin{array}{l}\text { Gum Arabic, } \\
\text { CMC }\end{array}$ & $\begin{array}{l}\text { Several } \\
\text { rhizobia; } B . \\
\text { japonicum }\end{array}$ & Soybean & $\begin{array}{l}\text { Albareda et al. } \\
(2008)\end{array}$ \\
\hline $\begin{array}{l}\text { Wastewater } \\
\text { sludge }\end{array}$ & $\begin{array}{l}\text { Acid, alkaline, } \\
\text { and oxidative } \\
\text { pretreatments }\end{array}$ & $\begin{array}{l}\text { S. meliloti, } \\
R . \\
\text { leguminosarum } \\
\text { bv. viciae, } \\
\text { B. japonicum, } \\
\text { B. elkanii }\end{array}$ & Not tested & $\begin{array}{l}\text { Ben Rebah et al. } \\
(2002 a, b)\end{array}$ \\
\hline \multicolumn{5}{|l|}{ Inorganic carrier } \\
\hline $\begin{array}{l}\text { Clay minerals, } \\
\text { perlite }\end{array}$ & $\begin{array}{l}\text { Gum Arabic, } \\
\text { CMC }\end{array}$ & $\begin{array}{l}\text { Several } \\
\text { rhizobia, } B . \\
\text { japonicum }\end{array}$ & Soybean & $\begin{array}{l}\text { Albareda et al. } \\
(2008)\end{array}$ \\
\hline Coal & None & $\begin{array}{l}R . \\
\text { leguminosarum } \\
\text { bv. phaseoli }\end{array}$ & Pinto bean & $\begin{array}{l}\text { Crawford and } \\
\text { Berryhill (1983) }\end{array}$ \\
\hline Vermiculite & None & $\begin{array}{l}\text { B. japonicum, } \\
\text { S. meliloti, } \\
R . \\
\text { leguminosarum } \\
\text { bv. phaseoli } \\
\end{array}$ & Navy beans & $\begin{array}{l}\text { Graham-Weiss } \\
\text { et al. (1987) and } \\
\text { Sparrow and } \\
\text { Ham (1983) }\end{array}$ \\
\hline \multirow[t]{2}{*}{ Perlite } & Gum Arabic & $\begin{array}{l}\text { Rhizobium, } \\
\text { Bradyrhizobium }\end{array}$ & $\begin{array}{l}\text { Bean; Lupinus, } \\
\text { Hedysarum; } \\
\text { soybean }\end{array}$ & $\begin{array}{l}\text { Temprano et al. } \\
(2002)\end{array}$ \\
\hline & Sucrose & $\begin{array}{l}R . \\
\text { leguminosarum } \\
\text { bv. phaseoli, } \\
\text { R. tropici, } \\
\text { B. japonicum } \\
\end{array}$ & Bean, soybean & $\begin{array}{l}\text { Daza et al. } \\
(2000)\end{array}$ \\
\hline \multicolumn{5}{|l|}{ Polymeric carrier } \\
\hline Alginate & None & Rhizobium spp. & $\begin{array}{l}\text { Leucaena } \\
\text { leucocephala }\end{array}$ & \begin{tabular}{|l} 
Forestier et al. \\
$(2001)$
\end{tabular} \\
\hline
\end{tabular}

Modified from Bashan et al. (2014)

growing on $25 \mathrm{M}$ ha of land fix US\$3-4 billion worth of $\mathrm{N}$ annually (Bullard et al. 2005). Report of Vessey (2004) states the benefits of rhizobial inoculants in the Northern Great Plains of the USA and Canada on soybean, lentil, pea, and faba bean with an overall response of $45 \%$ yield increase. In the context of Asia, the situation is typically different though it contributes for maximum production of pulses than the other regions/continents. The statistical data of FAO (FAOSTAT 2016) on top seed producers and fertilizer users clearly indicates that the major seed producers are India and China; also the two Asian countries are the relatively top consumers of fertilizers (Fig. 3.2). All these together give a clear indication that the Asian countries depend more toward $\mathrm{N}$ fertilizers than the biofertilizers contributing nitrogen 


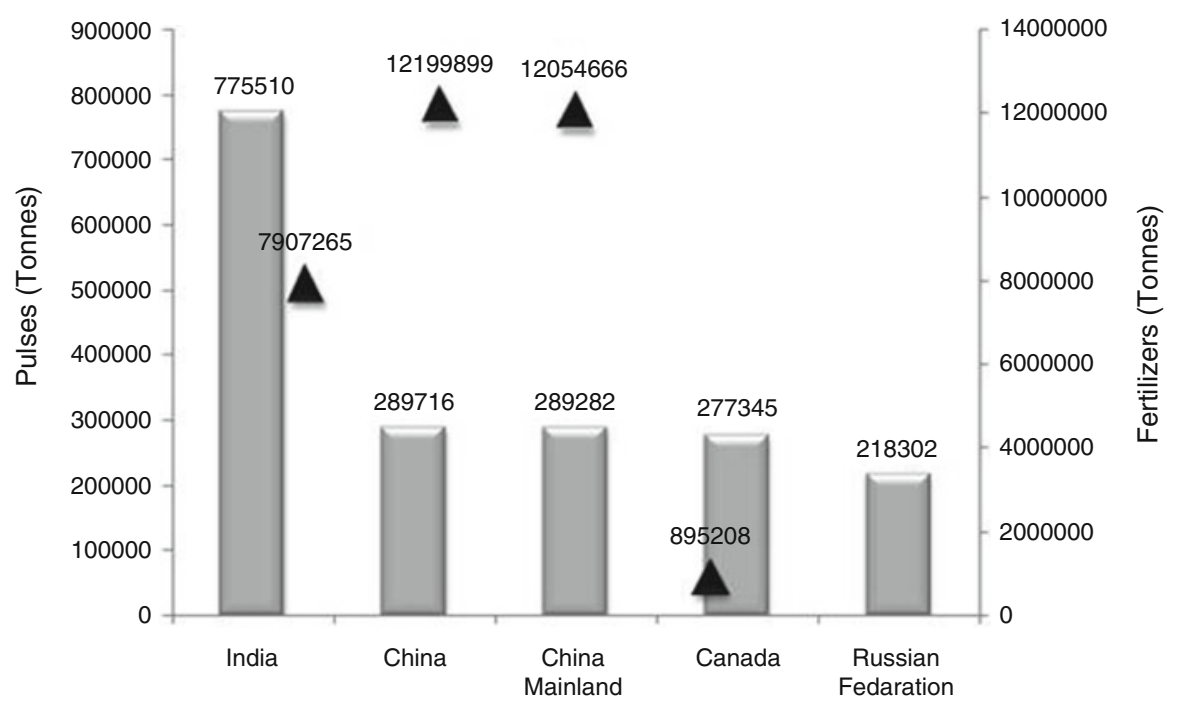

Top producing/consuming countries

Fig. 3.2 Top pulse producers and fertilizer consumers of the world (Note: $₫$ Top seed producer (based on average data of 1993-2013) on the left axis $\boldsymbol{\Delta}$ Top fertilizer consumers (based on average data of 2006-2009) on the right axis)

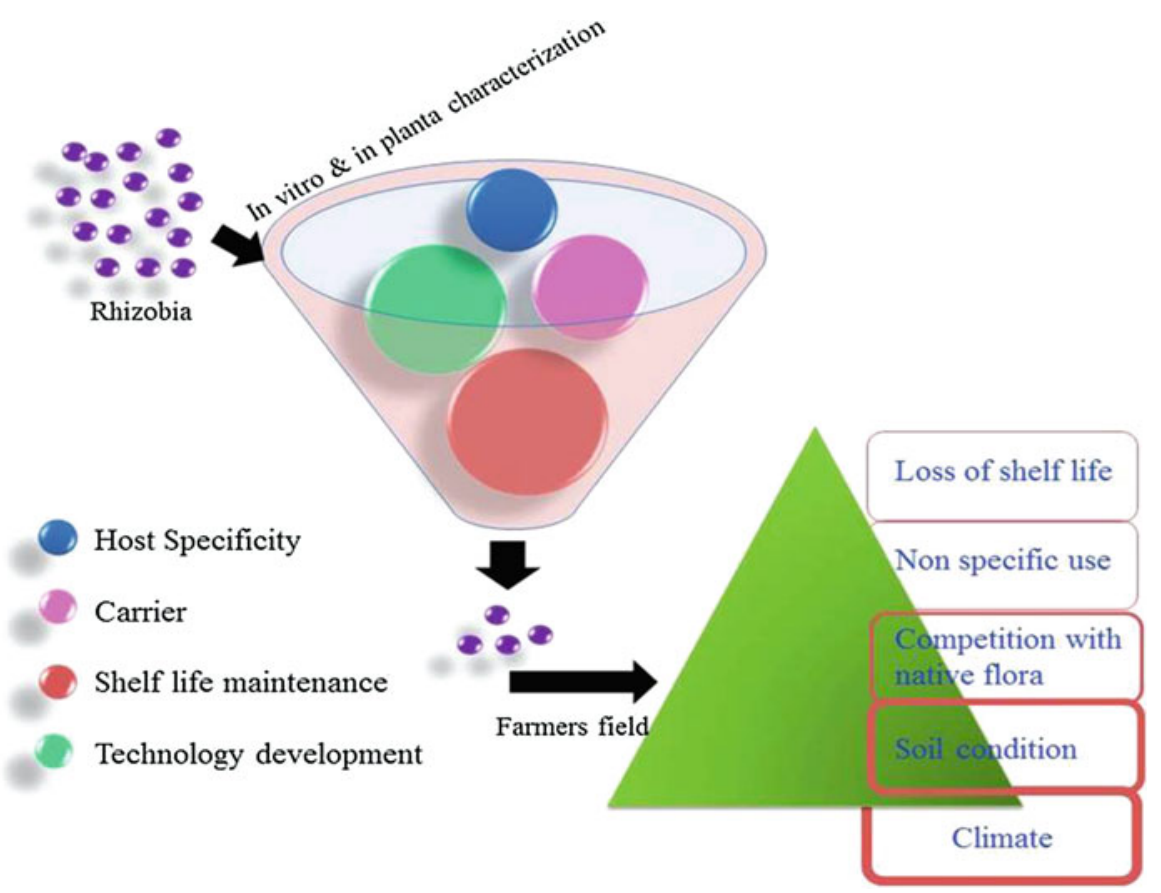

Fig. 3.3 Overview of barriers in inoculant development 
including Rhizobium inoculants. The problem in the context of Asian scenario in Rhizobium inoculant technology is described here in various aspects, and an overview is given in Fig. 3.3.

\subsubsection{Inoculant Strain Selection}

Effective rhizobial strain is the central core for developing an inoculant which is necessitated in order to provide rhizobia for new legume cultivars and species and extend and optimize the legume cultivation under fluctuating environmental conditions. Brockwell et al. (1995) have listed a set of essential and desirable characters for inoculant strains including host specificity, competence with native rhizobia population and also with agrochemicals, genetic stability, etc. Asian countries including India (Ansari et al. 2014), China (Jiao et al. 2015), Nepal (Adhikari et al. 2012), and Myanmar (Htwe et al. 2015) have been reported with vast diversity of nodulating rhizobia. Recent reports on diversity analysis of rhizobia under hostile environments such as soils with acidity (Mishra et al. 2014), alkalinity (Singh et al. 2016), and micronutrient deficiency (Unno et al. 2015) indicate the research initiatives on the exploration of Asian rhizobial strains. The large genetic diversity noticed on soybean native rhizobia of Asian countries further supports the phenomenon (Biate et al. 2014). Reeve et al. (2015) captured the phylogenetic and biogeographic diversity of root nodule bacteria across the world through two genome sequencing reports, which has only 7 entries for rhizobia from Asian origin among the 107 selected strains. However, these 7 entries include 3 among the total of 13 type strains and 1 among the total of 14 elite strains with commercial significance, indicating that the complete characterization and exploration of rhizobial biodiversity of Asian countries will pave way for inoculant development.

\subsubsection{Genetically Modified Rhizobia}

Besides the native flora, genetic modification has also been done in rhizobia, mainly to compete with the indigenous strains and to improve its efficacy to form nodules and to fix nitrogen.

\subsubsection{Modification in Nodulation}

To increase the nodulation efficiency, two approaches were carried out. One is by introducing genes encoding for trifoliotoxin, an antibiotic to which indigenous flora is sensitive. Robleto et al. (1998) used this construct in Rhizobium elti, the common bean microsymbiont. They differ with the indigenous strain only in the production of nodules. Over 2 years, the genetically modified strains had occupied $20 \%$ of the nodules in comparison to non-trifoliotoxin-producing strains. Another approach is to modify the expression of metabolite putA gene which is responsible for root surface colonization. Dillewijn et al. (2001) followed this approach in alfalfa field with $S$. meliloti strains overexpressing putA gene. On 1 month of inoculation, a large 
number of strains occupied the nodules than the control strains. It appears to be an efficient method of nodulation, but on the yield of crop after 3 years of experimentation, they were all equal in inoculated and un-inoculated plants. This informs that inoculant strains will improve in nodulation only when indigenous competing population is less efficient which might not be frequent.

\subsubsection{Modification in Nitrogen Fixation}

To improve the nitrogen fixation, two approaches were followed. One is involving modification in nifA gene which regulates the expression of genes necessary for enzymes involved in nitrogen fixation. The other is by modulating dicarboxylate transport $(d c t)$ genes which supplies the carbon and energy required for nitrogen fixation. A construct with extra copy of nifA and/or $d c t$ genes was inoculated in $S$. meliloti and released in four fields (Bosworth et al. 1994). There was an increase by 13 and $18 \%$ of alfalfa biomass in wild-type strains and non-inoculated control, respectively. But they were shown only at the sites with very low population of indigenous flora and low nitrogen content. Further, these were not found after 3 years of exploitation (Scupham et al. 1996). A study on soybean cultivation with release of B. japonicum with or without extra copy of nifA gene did not neither increase the yield nor the nitrogen fixation (Ronson et al. 1990). Summarily, the success of genetic modification has the potential to bring out a success in poor agricultural conditions.

\subsubsection{Interaction Between Indigenous and Genetically Modified Rhizobia}

In response to the introduction of genetically modified rhizobia, there was a change in number, composition, and activities of indigenous microflora and most importantly exchange genetic material with indigenous microflora. There were very less differences observed in rhizospheres of different hosts (Hirsch and Spokes 1994; Amarger et al. 2001) which informs only less changes happen on introduction. Similarly, vice versa transfer, i.e., plasmids from native flora to the introduced flora, was also not detected on re-isolating the genetically marked rhizobia after 1-2 years of introduction (Hirsch 1997). Data predicts that plasmid acquisition takes place at a frequency of $8 \times 10^{6} /$ recipient cell in one site after 7 years of release which is not a stable conjugant. Studies have reported that there is no transfer of Tn-7 plasmid that occurs at any stage. If occurred also, the frequency is less than $10^{7}$ events/gram of soil (Drahos et al. 1986). Lilley and Bailey (1997) had reported that transfer from indigenous to genetically marked rhizobia takes place with a frequency from $5 \times 10^{7}$ to 1 per recipient which varies with the year of experiment. However, the generated transconjugant is not stably maintained in the cell.

\subsubsection{Nutritional Attributes for Rhizobia}

After the selection of effective rhizobia, nutritional attributes have to be considered in order to evaluate whether the given carrier material will be enough to hold the viability or it requires any additional supplements for rhizobial maintenance. 
Knowledge of nutritional requirement is a key factor when selecting complex material like agricultural, industrial, and sewage sludge wastes for inoculant production. Broadly rhizobia are divided into two categories depending on nutritional requirement and growth rate. They are fast-growing and slow-growing rhizobia which are placed in the genus Rhizobium and Bradyrhizobium, respectively (Jordan 1984). Fast growers are acid producers with $2-4 \mathrm{~h}$ as generation time. Slow growers are alkaline producers with 6-8 h as generation time (Jordan 1984). Fast growers can grow on various carbon sources such as hexoses, pentoses, disaccharides, trisaccharides, and organic acids (Allen and Allen 1950), whereas the other type can grow only in the presence of pentose but can utilize many aromatic substrates (Parke and Ornston 1984). In the context of nitrogen, some fast growers are potent in utilizing nitrate, ammonia, and amino acids (Quispel 1974). Amino acid glycine, alanine, and certain D-forms of amino acid might create a negative impact in nitrogen fixation (Burton 1979). Vitamin requirements vary between the genera, for example, $R$. leguminosarum (bv. trifolii and bv. phaseoli) requires biotin, thiamine, or calcium pantothenate separately or in combination, whereas $S$. meliloti, B. japonicum, etc. need only biotin (Graham 1963). In case of minerals, deficiency of $\mathrm{Ca}^{2+}$ and $\mathrm{Mg}^{2+}$ affects the growth and results in abnormal cells (Vincent 1962).

\subsubsection{Inoculant Development}

Among the inoculants are the primitive types such as broth culture, agar culture, and dried/lyophilized cells. These types of inoculants could not be promoted to practical technology, though it is least laborious and has proved records at research centers, because of impractical application at large scales and its failure to meet economic and commercial needs (Bashan et al. 2014). Hence, a carrier is necessary for the development of a successful inoculant.

The major markets, such as Europe and Australia, supply the inoculants in solid carriers, most commonly peat, for seed application (Catroux et al. 2001; Singleton et al. 2002). However, in North and South America, the inoculants supplied are clay- and peat-based granular and liquid inoculants (Singleton et al. 2002; Xavier et al. 2004). The Asian market also depends on peat for its inoculants because of its potential in holding high numbers of rhizobia (greater than $10^{8}$ cells/g) during the storage. Unlikely, they do not have enough peatlands due to the lack of harmonized policies related to the management of peatlands besides their presence in Indonesia, India, Malaysia, Myanmar, the Philippines, Singapore, Thailand, and Vietnam. In the last few years, a forward look for its sustainable management has arisen. The projects ASEAN Peat 1 and Forests Project (APFP) and SEApeat were aimed in reducing deforestation and degradation of peatland forests and to strengthen the policies for its management. On the other end, a large area of peatlands in Vietnam has been designated as protected area and national parks (http://www.aseanpeat. net/).

It should also be considered that whether the peat belongs to these regions is original peat. Thomas et al. (1974) have evaluated the physicochemical characters of peat obtained from Nilgiri reserves of India and concluded that the material was 
not an original peat as it lacks the main traits like water-holding capacity and organic carbon content. It is noticed that the Indian peat has $20-50 \%$ organic carbon, whereas Australian and American peat has 65 and $86 \%$ organic carbon content, respectively (NIIR 2004). Conservation policies for peatland management by Europe, Australia, and America have become stringent as they have key roles in biodiversity, carbon sequestration, and fuel-related application. This indirectly leads to the unavailability and high export cost for other countries (Joosten 2015).

As an alternative to peat, other organic carriers such as lignite and charcoal can be used which have also proved to be efficient in carrying rhizobia with the shelf life of 4-6 months (Argal et al. 2015; Gao et al. 2015). Research on alternate carrier was started more than four decades ago on carriers such as lignite and coal, clays and mineral soils, compost, farmyard manure, pressmud, agricultural waste, and inorganic materials like vermiculite, perlite, ground rock phosphate, calcium sulfate, polyacrylamide gels, and alginate (Kandasamy and Prasad 1971; Dube et al. 1980; Chao and Alexander 1984; Iswaran et al. 1972; Philip and Jauhri 1984; Sadasivam et al. 1986; Sparrow and Ham 1983; Dommergues et al. 1979; Jung et al. 1982).

There are numerous reports on research and development of successful rhizobial formulations which were tested in fields of various research stations. However, there are very few number of coordinated network projects on large-scale evaluation in Asian countries. On the contrary, the International Network of Legume Inoculation Trials (INLIT) funded by the US Agency for International Development (USAID) in the University of Hawaii's NifTAL project assessed the need for inoculation in tropical agricultural systems by conducting 228 trials on various legumes such as green gram, soybean, black gram, groundnut, cowpea, chickpea, lentil, pigeon pea, and common bean. Worldwide Rhizobial Ecology Network (WREN), the follow-up program of NifTAL, evaluated the factors contributing to variations in inoculation response including a number of infective rhizobia, edaphic characteristics, crop fixed-N demand, and soil fixed-N supply (Singleton et al. 1992).

Effective regulatory quality control (QC) program has key role in the successful production of rhizobial inoculants. This may be supported by appropriate legislation as in Canada, Uruguay, and France or may be voluntary as in Australia, Thailand, New Zealand, and South Africa. Contrarily, in the USA, regulatory control and independent testing are considered unnecessary, with manufacturers conducting their own internal QC. Irrespective of the QC nature, all QC programs should monitor the numbers and quality of the strains in the inoculants along with the contaminating microorganisms. In Asia, $90 \%$ of inoculants sampled had $<10^{8}$ rhizobia $^{-1}$ carrier and most of samples were contaminated (Thompson 1992).

Besides these barriers, many Asian countries commercialized rhizobia inoculants. This includes the following: (1) Pakistan, Fasloon Ka Jarasimi Teeka (AARI), BioPower (NIBGE), Biozote (NARC), and Rhizogold (ISES, UAF), consists of Rhizobium sp. (Naveed et al. 2015), and (2) Japan, the Tokachi Federation of Agricultural Cooperative (TFAC), produces Mamezo (rhizobia are mixed with peat and the natural organic matters), R-processing seeds (leguminous seeds inoculated with rhizobia), and hyper-coating seeds (leguminous grass seed coated by rhizobia within the capsule of calcium carbonate) (Yokoyama and Ohyama 2007). 


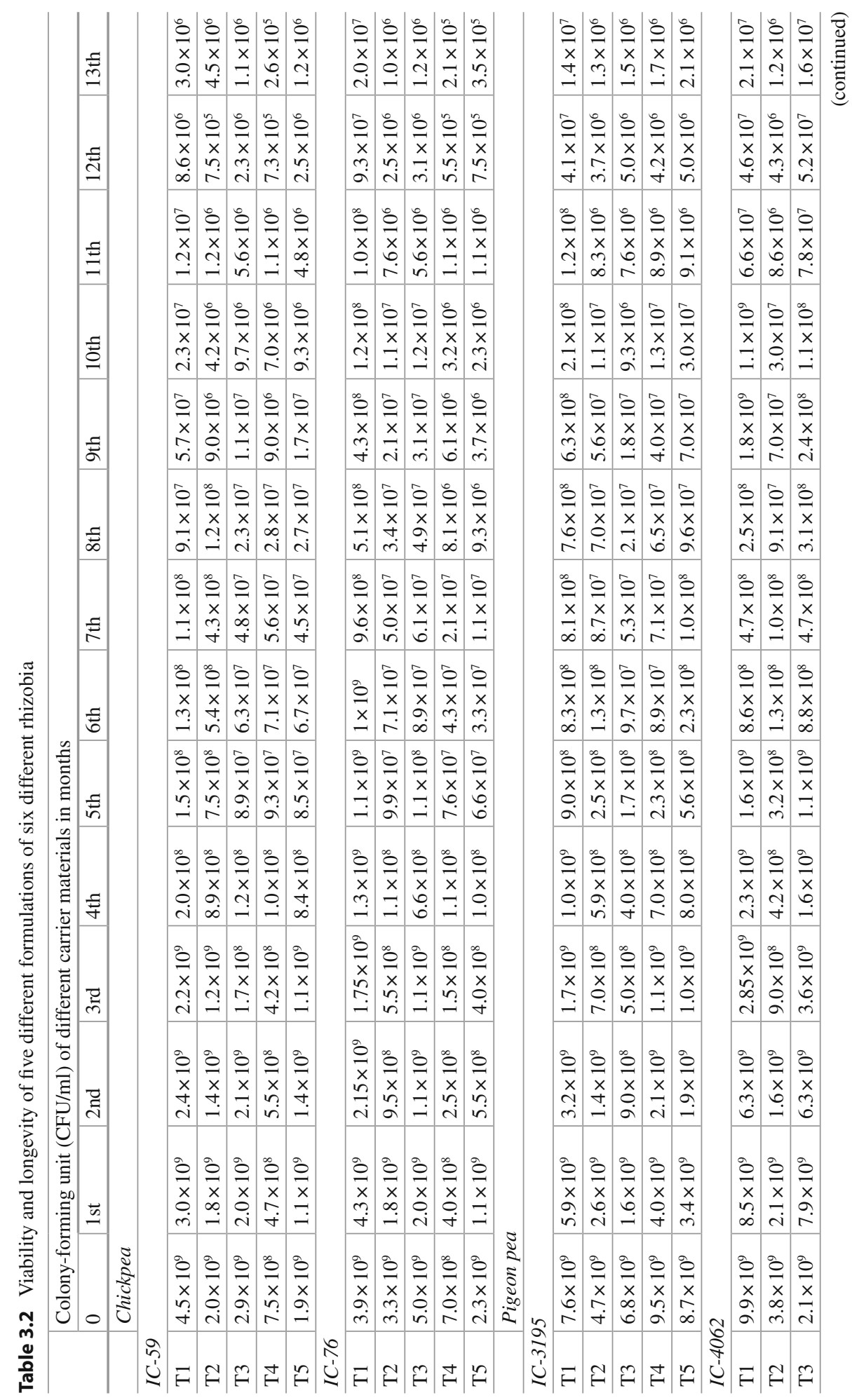




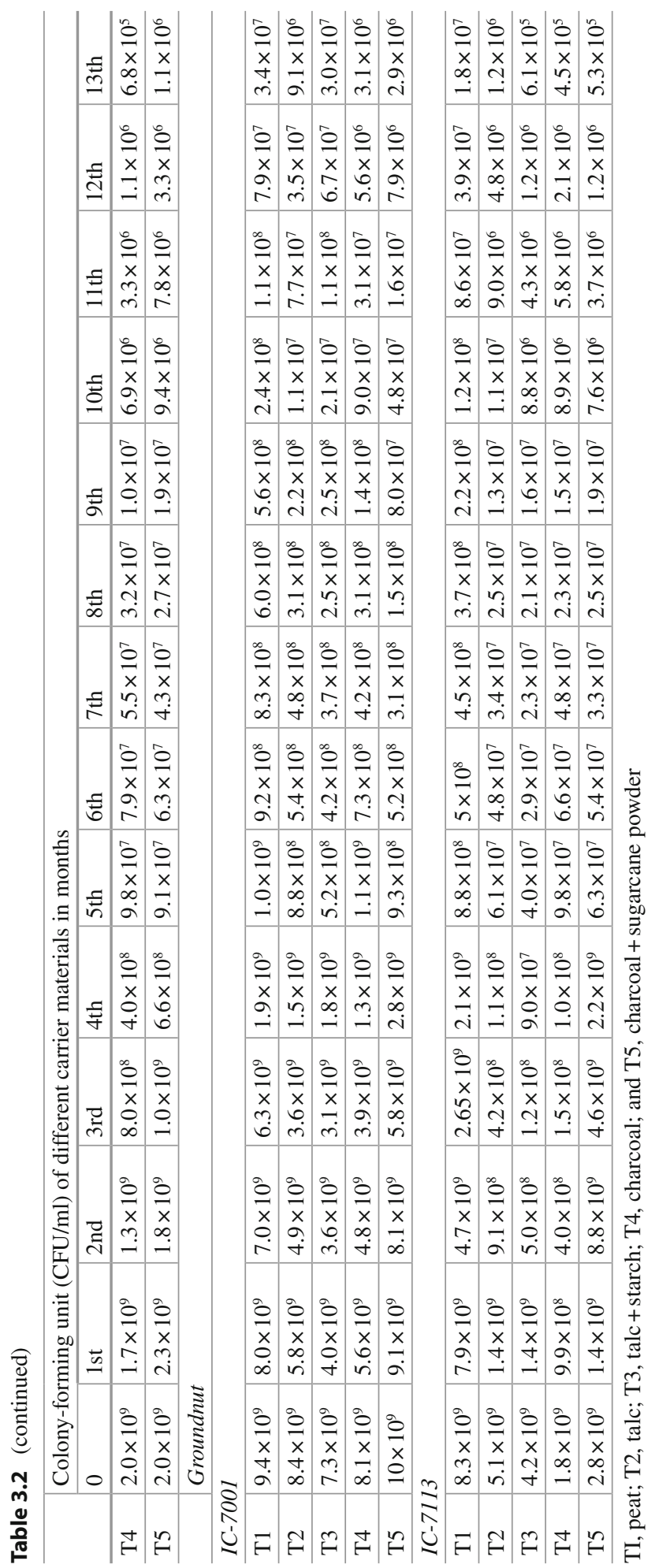




\subsection{Work at ICRISAT}

International Crops Research Institute for the Semi-Arid Tropics (ICRISAT), based at Patancheru, Hyderabad, India, has been using peat-based rhizobial formulation for its mandate crops chickpea, pigeon pea, and groundnut. In order to find an efficient alternative carrier material, a total of six rhizobia (two specific for chickpea, IC-59, IC-76; two specific for pigeon pea, IC-3195, IC-4062; two specific for groundnut, IC-7001, IC-7113) were formulated as five different inoculants using peat, talc, talc amended with starch, charcoal, and charcoal amended with sugarcane powder, and shelf life was evaluated for a period of 13 months (Table 3.2). Among the carrier materials, peat was found to be the best as it holds $10^{7}$ rhizobia for IC-76, IC-3195, IC-4062, IC-7001, and IC-7113 and $10^{6}$ for IC-59 even after 13 months of storage. On the whole, the shelf life maintenance was observed in the order of peat $>$ talc amended with starch $>$ talc $>$ charcoal amended with sugar cane powder $>$ charcoal. The results also suggest that the use of proper additives to the inoculants can tremendously enhance the shelf life of the product.

\subsection{Conclusions}

From the literature survey, it is observed that legume inoculants gained more attention in developed countries with successful stories like soybean in Brazil, pea and lentil in Canada, and subterranean clover in Australia. In Asia, though there is a considerable interest in rhizobial inoculant development, still many factors such as undisturbed supply of good-quality carrier material, well-developed technology, quality control legislations, well-defined good manufacturing practices, training programs, well-planned field demonstrations, and governmental support for smallscale industries are creating constraints for further development. Unification of all these sectors can lead to the development of a low cost, high shelf life, and highly effective rhizobial inoculants.

\section{References}

Adhikari D, Kaneto M, Itoh K, Suyama K, Pokharel BB, Gaihre YK (2012) Genetic diversity of soybean-nodulating rhizobia in Nepal in relation to climate and soil properties. Plant Soil 357(1-2):131-145

Afzal A, Bano A (2008) Rhizobium and phosphate solubilizing bacteria improve the yield and phosphorus uptake in wheat (Triticum aestivum L.). Int J Agric Biol 10:85-88

Albareda M, Rodriguez-Navarro DN, Camacho M, Temprano FJ (2008) Alternatives to peat as a carrier for rhizobia inoculant: solid and liquid formulations. Soil Biol Biochem 40:2771-2779

Albareda M, Rodriguez-Navarro DN, Temprano FJ (2009) Use of Sinorhizobium (Ensifer) fredii for soybean inoculants in south Spain. Eur J Agron 30:205-211

Allen EK, Allen ON (1950) Biochemical and symbiotic properties of the rhizobia. Bacteriol Rev $14: 273-330$ 
Amarger N, Hirsch P, Klingmüller W (2001) Assessing the risks involved in the release of genetically manipulated microorganisms. In: Kessler C, Economidis I (eds) EC-sponsored research on safety of genetically modified organisms. A review of results. European Communities, Luxembourg, pp 62-64

Ansari PG, Rao DLN, Pal KK (2014) Diversity and phylogeny of soybean rhizobia in central India. Ann Microbiol 64(4):1553-1565

Argal MS, Rawat AK, Aher SB, Rajput PS (2015) Bioefficacy and shelf life of Rhizobium leguminosarum loaded on different carriers. Appl Biol Res 17(2):1-7

Arora NK, Kang SC, Maheshwari DK (2001) Isolation of siderophore producing strains of Rhizobium meliloti and their biocontrol potential against Macrophomina phaseolina that causes charcoal rot of groundnut. Curr Sci 81:673-677

Arora NK, Khare E, Naraian R, Maheshwar DK (2008) Sawdust as a superior carrier for production of multipurpose bioinoculant using plant growth-promoting rhizobial and pseudomonad strains and their impact on productivity of Trifolium repens. Curr Sci 95:90-94

Bashan Y, de-Bashan LE, Prabhu SR, Hernandez JP (2014) Advances in plant growth-promoting bacterial inoculant technology: formulations and practical perspectives (1998-2013). Plant Soil 378(1-2):1-33

Ben Rebah F, Tyagi RD, Prevost D (2002a) Wastewater sludge as a substrate for growth and carrier for rhizobia: the effect of storage conditions on survival of Sinorhizobium meliloti. Bioresour Technol 83:145-151

Ben Rebah F, Tyagi RD, Prevost D, Surampalli RY (2002b) Wastewater sludge as a new medium for rhizobial growth. Water Qual Res J Can 37:353-370

Bhattacharyya PN, Jha DK (2012) Plant growth-promoting rhizobacteria (PGPR): emergence in agriculture. World J Microbiol Biotechnol 28:1327-1350

Biate DL, Kumar LV, Ramadoss D, Kumari A, Naik S, Reddy KK, Annapurna K (2014) Genetic diversity of soybean root nodulating bacteria. In: Maheshwari DK (ed) Bacterial diversity in sustainable agriculture. Springer, Cham, pp 131-145

Boiero L, Perrig D, Masciarelli O, Penna C, Cassan F, Luna V (2007) Phytohormone production by three strains of Bradyrhizobium japonicum and possible physiological and technological implications. Appl Microbiol Biotechnol 74:874-880

Bosworth AH, Williams MK, Albrecht KA, Kwiatkowski R, Beynon J, Hankinson TR, Ronson CW, Cannon F, Wacek TJ, Triplett EW (1994) Alfalfa yield response to inoculation with recombinant strains of Rhizobium meliloti with an extra copy of dctABD and/or modified nifA expression. Appl Environ Microbiol 60:3815-3832

Bramley RGV, Ellis N, Nable RO, Garside AL (1996) Changes in soil chemical properties under long-term sugar cane monoculture and their possible role in sugar yield decline. Aust J Soil Sci 34:967-984

Brockwell J, Bottomley PJ, Thies JE (1995) Manipulation of rhizobia microflora for improving legume productivity and soil fertility: a critical assessment. Plant Soil 174:143-180

Bullard GK, Roughley RJ, Pulsford DJ (2005) The legume inoculant industry and inoculant quality control in Australia: 1953-2003. Aust J Exp Agric 45:127-140

Burton JC (1979) Rhizobium species. In: Peppler HJ, Perlman D (eds) Microbial technology: Microbial processes. Academic, New York, pp 29-58

Camerini S, Senatore B, Lonardo E, Imperlini E, Bianco C, Moschetti G, Rotino GL, Campion B, Defez R (2008) Introduction of a novel pathway for IAA biosynthesis to rhizobia alters vetch root nodule development. Arch Microbiol 190:67-77

Carson KC, Meyer JM, Dilworth MJ (2000) Hydroxamate siderophore of root nodule bacteria. Soil Biol Biochem 32:11-21

Catroux G, Hartmann A, Revellin C (2001) Trends in rhizobial inoculant production and use. Plant Soil 230(1):21-30

Chandra S, Choure K, Dubey RC, Maheshwari DK (2007) Rhizosphere competent Mesorhizobium loti MP6 induces root hair curling, inhibits Sclerotinia sclerotiorum and enhances growth of Indian mustard (Brassica campestris). Braz J Microbiol 38:128-130

Chao WL, Alexander M (1984) Mineral soils as carriers for Rhizobium inoculants. Appl Environ Microbiol 47:94-97 
Clayton GW, Rice WA, Lupwayi NZ, Johnston AM, Lafond GP, Grant CA, Walley F (2004a) Inoculant formulation and fertilizer nitrogen effects on field pea: crop yield and seed quality. Can J Plant Sci 84:89-96

Clayton GW, Rice WA, Lupwayi NZ, Johnston AM, Lafond GR, Grant CA, Walley F (2004b) Inoculant formulation and fertilizer nitrogen effects on field pea: Nodulation, N2 fixation and nitrogen partitioning. Can J Plant Sci 84:79-88

Crawford SL, Berryhill DL (1983) Survival of Rhizobium phaseoli in coal-based legume inoculants applied to seeds. Appl Environ Microbiol 45:703-705

Daza A, Santamaria C, Rodriguez-Navarro DN, Camacho M, Orive R, Temprano F (2000) Perlite as a carrier for bacterial inoculants. Soil Biol Biochem 32:567-572

Deaker R, Roughley RJ, Kennedy IR (2004) Legume seed inoculation technology - a review. Soil Biol Biochem 36:1275-1288

Deshwal VK, Pandey P, Kang SC, Maheshwari DK (2003) Rhizobia as a biological control agent against soil borne plant pathogenic fungi. Ind J Exp Biol 41:1160-1164

Dillewijn P, Soto MJ, Villadas PJ, Toro N (2001) Construction and environmental release of a Sinorhizobium meliloti strain genetically modified to be more competitive for alfalfa nodulation. Appl Environ Microbiol 67:3860-3865

Diouf D, Forestier S, Neyra M, Lesueur D (2003) Optimisation of inoculation of Leucaena leucocephala and Acacia mangium with Rhizobium under greenhouse conditions. Ann For Sci 60:379-384

Dobbelaere S, Vanderleyden J, Okon Y (2003) Plant growth-promoting effects of diazotrophs in the rhizosphere. Crit Rev Plant Sci 22:107-149

Dommergues YR (1995) Nitrogen fixation by trees in relation to soil nitrogen economy. Fertil Res 42(1):215-230

Dommergues YR, Diem HG, Divies C (1979) Polyacrylamide entrapped Rhizobium as an inoculant for legumes. Appl Environ Microbiol 37:779-981

Drahos DJ, Hemming BC, McPherson S (1986) Tracking recombinant organisms in the environment: beta-galactosidase as a selectable non-antibiotic marker for fluorescent pseudomonads. Biotechnology 4:439-444

Dube JN, Mahere DP, Bawat AF (1980) Development of coal as a carrier for rhizobial inoculants. Sci Cult 46:304

FAOSTAT Data (2016) Food and Agriculture Organization of the United Nations. Statistical database. Accessed at http://faostat3.fao.org/browse/Q/QC/E and, http://faostat3.fao.org/browse/R/ $\mathrm{RF} / \mathrm{E}$ on 8 Mar 2016

Fink CR, Waggoner PE, Ausubel F (1999) Nitrogen fertilizer: retrospect and prospect. Proc Natl Acad Sci USA 96:1175-1180

Forestier S, Alvarado G, Badjel SB, Lesueur D (2001) Effect of Rhizobium inoculation methodologies on nodulation and growth of Leucaena leucocephala. World J Microbiol Biotechnol 17:359-362

Fred EB, Baldwin IL, McCoy E (1932) Root nodule bacteria and leguminous plants. University of Wisconsin Press, Madison

Gao TG, Xu YY, Jiang F, Li BZ, Yang JS, Wang ET, Yuan HL (2015) Nodulation characterization and proteomic profiling of Bradyrhizobium liaoningense CCBAU05525 in response to watersoluble humic materials. Scientific reports, 5

Gopalakrishnan S, Sathya A, Vijayabharathi R, Srinivas V (2016) Formulations of plant growthpromoting microbes for field applications. In: Singh DP, Singh HB, Prabha R (eds) Microbial inoculants in sustainable agricultural productivity. Springer, New Delhi. doi:10.1007/978-81-322-2644-4_15

Gopalakrishnan S, Sathya A, Vijayabharathi R, Varshney RK, Gowda CLL, Krishnamurthy L (2014) Plant growth-promoting rhizobia: Challenges and opportunities. 3 Biotech. doi:10.1007/ s13205-014-0241-x

Graham PH (1963) Vitamin requirements of root-nodule bacteria. J Gen Microbiol 30:245-248

Graham PH (1992) Stress tolerance in Rhizobium and Bradyrhizobium and nodulation under adverse soil conditions. Can J Microbiol 38:475-484 
Graham-Weiss L, Bennett ML, Alan SP (1987) Production of bacterial inoculants by direct fermentation on nutrient-supplemented vermiculite. Appl Environ Microbiol 53(9):2138-2140

Grover M, Ali SZ, Sandhya V, Rasul A, Venkateswarlu B (2010) Role of microorganisms in adaptation of agriculture crops to abiotic stresses. World J Microbiol Biotechnol 27:1231-1240

Guthrie FB (1896) Inoculation of soil for leguminous crops. Agric Gaz NSW 7:690-694

Halder AK, Chakrabarty PK (1993) Solubilization of inorganic phosphate by Rhizobium. Folia Microbiol 38:325-330

Halder AK, Mishra AK, Bhattacharya P, Chakrabarthy PK (1990) Solubilization of rock phosphate by Rhizobium and Bradyrhizobium. J Gen Appl Microbiol 36:1-92

Hamaoui B, Abbadi JM, Burdman S, Rashid A, Sarig S, Okon Y (2001) Effects of inoculation with Azospirillum brasilense on chickpeas (Cicer arietinum) and faba beans (Vicia faba) under different growth conditions. Agronomie 21:553-560

Herridge DF, Peoples MB, Boddey RM (2008) Global inputs of biological nitrogen fixation in agricultural systems. Plant Soil 311(1):1-18

Hirsch PR (1997) Acquisition of genes from indigenous bacteria by inoculant strains at long-term release sites. In: Hoeveler A, Cresti M (eds) Biotechnology programme (1992-1994), final report. European Commission, Luxembourg, pp 231-234

Hirsch PR, Spokes JD (1994) Survival and dispersion of genetically modified rhizobia in the field and genetic interactions with native strains. FEMS Microbiol Ecol 15:147-159

Htwe AZ, Yamakawa T, Sarr PS, Sakata T (2015) Diversity and distribution of soybean-nodulating bradyrhizobia isolated from major soybean-growing regions in Myanmar. Afr J Microbiol Res 9(43):2183-2196

Huang J, Rozelle S (1995) Environmental stress and grain yields in China. Am J Agric Econ 77:853-864

Hungria M, Campo RJ, Souza EM, Pedrosa FO (2010) Inoculation with selected strains of Azospirillum brasilense and A. lipoferum improves yields of maize and wheat in Brazil. Plant Soil 331:413-425

Hynes RK, Jans DC, Bremer E, Lupwayi NZ, Rice WA, Clayton GW, Collins MM (2001) Rhizobium population dynamics in the pea rhizosphere of rhizobial inoculant strain applied in different formulations. Can J Microbiol 47:595-600

Iswaran V, Sen A, Apte R (1972) Plant compost as a substitute for peat for legume inoculants. Curr Sci 41:299

Jiao YS, Liu YH, Yan H, Wang ET, Tian CF, Chen WX, Guo BL, Chen WF (2015) Rhizobial diversity and nodulation characteristics of the extremely promiscuous legume Sophora flavescens. Mol Plant Microbe Interact 28(12):1338-1352

Jiao J, Wu LJ, Zhang B, Hu Y, Li Y, Zhang XX, Guo HJ, Liu LX, Chen W, Zhang Z, Tian CF (2016) MucR is required for transcriptional activation of conserved ion transporters to support nitrogen fixation of Sinorhizobium fredii in soybean nodules. Mol Plant Microbe Interact. doi:http:// dx.doi.org/10.1094/MPMI-01-16-0019-R

Joosten H (2015) Peatlands, climate change mitigation and biodiversity conservation: An issue brief on the importance of peatlands for carbon and biodiversity conservation and the role of drained peatlands as greenhouse gas emission hotspots, vol 2015727. Nordic Council of Ministers, Denmark

Jordan DC (1984) Family III Rhizobiaceae. In: Kneg NR, Holt JG (eds) Bergey's manual of systematic bacteriology. Williams \& Wilkins, Baltimore, pp 234-244

Jung G, Mugnier J, Diem HG, Dommergues YR (1982) Polymer-entrapped Rhizobium as an inoculant for legumes. Plant Soil 65(2):219-231

Kandasamy R, Prasad NN (1971) Lignite as a carrier of rhizobia. Curr Sci 40:496

Keyser HH, Somasegaran P, Bohlool BB (1993) Rhizobial ecology and technology. In: Metting EB (ed) Soil microbial ecology: applications in agricultural and environmental management. Marcel Dekker, New York, pp 205-226

Khalid A, Arshad M, Zahir ZA (2004) Screening plant growth-promoting rhizobacteria for improving growth and yield of wheat. J Appl Microbiol 96:473-480

Kinzig AP, Socolow RH (1995) Is nitrogen fertilizer use nearing a balance? Phys Today 47:24-35 
Kloepper JW, Schroth MN (1978) Plant growth-promoting rhizobacteria on radishes. In: Proceedings of the 4th international conference on plant pathogenic bacteria, pp 879-882

Kostov O, Lynch JM (1998) Composted sawdust as a carrier for Bradyrhizobium, Rhizobium and Azospirillum in crop inoculation. World J Microbol Biol 14:389-397

Kremer RJ, Peterson HL (1983) Field evaluation of selected Rhizobium in an improved legume inoculant. Agron J 75:139-143

Kulkarni S, Nautiyal CS (2000) Effects of salt and pH stress on temperature tolerant Rhizobium sp. NBRI330 nodulating Prosopis juliflora. Curr Microbiol 40:221-226

Lilley AK, Bailey MJ (1997) The acquisition of indigenous plasmids by a genetically marked pseudomonad population colonizing the sugar beet phytosphere is related to local environmental conditions. Appl Environ Microbiol 63:1577-1583

Lindström K, Mousavi SA (2010) Rhizobium and other N-fixing symbioses. In: Encyclopedia of Life Sciences (ELS). Wiley, Chichester

Lindström K, Murwira M, Willems A, Altier N (2010) The biodiversity of beneficial microbe-host mutualism: the case of rhizobia. Res Microbiol 161(6):453-463

Mannion AM (1998) Future trends in agriculture: the role of biotechnology. Outlook Agric 27:219-224

Maurice S, Beauclair P, Giraud JJ, Sommer G, Hartmann A, Catroux G (2001) Survival and change in physiological state of Bradyrhizobiu mjaponicum in soybean (Glycine max L. Merril) liquid inoculants after long-term storage. World J Microbol Biotechnol 17:635-643

Mishra AC, Pandey VK, Rai VP (2014) Effectiveness of fertilizer doses, liming and Rhizobium inoculation in vegetable pea under acidic soil of Jharkhand. Asian J Hortic 9(1):140-142

Naveed M, MehboobI HMB, Ahmad Z (2015) Perspectives of rhizobial inoculation for sustainable crop production. In: Arora NK (ed) Plant microbes symbiosis: applied facets. Springer, New Delhi, pp 209-239

Nehra V, Choudhary M (2015) A review on plant growth-promoting rhizobacteria acting as bioinoculants and their biological approach towards the production of sustainable agriculture. J Appl Nat Sci 7(1):540-556

NIIR (2004) The complete technology book on bio-fertilizer and organic farming. National Institute of Industrial Research, New Delhi

Okazaki S, Tittabutr P, Teulet A, Thouin J, Fardoux J, Chaintreuil C, Gully D, Arrighi J, Furuta N, Miwa H, Yasuda M, Nouwen N, Teaumroong N, Giraud E (2016) Rhizobium-legume symbiosis in the absence of Nod factors: two possible scenarios with or without the T3SS. ISME J 10:64-74

Ozkoc I, Deliveli MH (2001) In vitro inhibition of the mycelial growth of some root rot fungi by Rhizobium leguminosarum biovar phaseoli isolates. Turk J Biol 25:435-445

Parke DL, Ornston LN (1984) Nutritional diversity of Rhizobiaceae revealed by auxanography. J Gen Microbiol 130:1743-1750

Peix A, Rivas-Boyero AA, Mateos PF, Rodriguez-Barrueco C, Martınez-Molina E, Velazquez E (2001) Growth promotion of chickpea and barley by a phosphate solubilizing strain of Mesorhizobium mediterraneum under growth. Soil Biol Biochem 33:103-110

Perret X, Staehelin C, Broughton WJ (2000) Molecular basis of symbiotic promiscuity. MicrobiolMol Biol Rev 64:180-201

Philip K, Jauhri KS (1984) A potential carrier for Rhizobium and Azotobacter 1. Comparative analytical studies of various carrier materials. J Microbiol 139:35-41

Quispel A (1974) The biology of nitrogen fixation. North-Holland Publishing Company, Amsterdam

Raja Sekar K, Karmegam N (2010) Earthworm casts as an alternate carrier material for biofertilizers: assessment of endurance and viability of Azotobacter chroococcum, Bacillus megaterium and Rhizobium leguminosarum. Sci Hortic 124:286-289

Reeve W, Ardley J, Tian R, Eshragi L, Yoon JW, Ngamwisetkun P, Seshadri R, Ivanova NN, Kyrpides NC (2015) A genomic encyclopedia of the root nodule bacteria: Assessing genetic diversity through a systematic biogeographic survey. Stand Genomic Sci 10:14

Remigi P, Zhu J, Young JPW, Masson-Boivin C (2016) Symbiosis within symbiosis: evolving nitrogen-fixing legume symbionts. Trends Microbiol 24(1):63-75 
Revellin C, Meunier G, Giraud J-J, Sommer G, Wadoux P, Catroux G (2000) Changes in the physiological and agricultural characteristics of peat-based Bradyrhizobium japonicum inoculants after long-term storage. Appl Microbiol Biotechnol 54:206-211

Robleto EA, Kmiecik K, Oplinger ES, Nienhuis J, Triplett EW (1998) Trifolitoxin production increases nodulation competitiveness of Rhizobium etli CE3 under agricultural conditions. Appl Environ Microbiol 64:2630-2633

Ronson CW, Bosworth A, Genova M, Gusbrandsen S, Hankinson T, Kwiatkowski R, Robie C, Sweeney P, Szeto W, Williams M, Zablotowitcz R (1990) Field release of geneticallyengineered Rhizobium meliloti and Bradyrhizobium japonicum strains. In: Gressoff PM, Roth LE, Stacey G, Newton WE (eds) Nitrogen fixation: achievements and perspectives. Chapman and Hall, New York/London, pp 397-403

Rozelle S, Veeck G, Huang JK (1997) The impact of environmental degradation on grain production in China 1975-1990. Econ Geog 73:44-66

Sadasivam KV, Tyagi RK, Ramarethinam S (1986) Evaluation of some agricultural wastes as carriers for bacterial inoculants. Agric Wastes 17:301-306

Savant NK, Datnoff LE, Snyder GH (1997) Depletion of plant-available silicon in soils: A possible cause of declining rice yields. Comm Soil Sci Plant Nutr 28:1245-1252

Scupham AJ, Bosworth AH, Ellis WR, Wacek TJ, Albrecht KA, Triplett EW (1996) Inoculation with Sinorhizobium meliloti RMBPC-2 increases alfalfa yield compared with inoculation with a non-engineered wild-type strain. Appl Environ Microbiol 62:4260-4262

Senthilkumar M, Madhaiyan M, Sundaram SP, Kannaiyan S (2009) Intercellular colonization and growth promoting effects of Methylobacterium sp. with plant-growth regulators on rice (Oryza sativa $\mathrm{L}$. CvCO-43). Microbiol Res 164:92-104

Singh RP, Manchanda G, Singh RN, Srivastava AK, Dubey RC (2016) Selection of alkalotolerant and symbiotically efficient chickpea nodulating rhizobia from North-West Indo Gangetic Plains. J Basic Microbiol 56(1):14-25

Singleton PW, Bohlool BB, Nakao PL (1992) Legume response to rhizobial inoculation in the tropics: Myths and realities. In: Lal R, Sanchez PA (eds) Myths and science of soils of the tropics. Soil Science Society of America and American Society of Agronomy Special Publication, Madison, pp 135-155

Singleton P, Keyser H, Sande E (2002) Development and evaluation of liquid inoculants. In: Herridge D (ed) Inoculants and nitrogen fixation of legumes in Vietnam. ACIAR Proceedings, Canberra, pp 52-66

Sparrow SD, Ham GE (1983) Nodulation, N2 fixation, and seed yield of navy beans as influenced by inoculant rate and inoculant carrier. Agron J 75:20-24

Temprano FJ, Albareda M, Camacho M, Daza A, Santamaría C, Rodríguez-Navarro DN (2002) Survival of several Rhizobium/Bradyrhizobium strains on different inoculant formulations and inoculated seeds. Int Microbiol 5:81-86

Thomas PK, Venkataramanan C, Vasu K (1974) Quality and quantity of peat material reserves in the Nilgiris. Proc Ind Natl Sci Acad 40:608

Thompson JA (1992) Consultant report to UNFAO. IND/86/003. FAO, Rome

Unno Y, Shinano T, Minamisawa K, Ikeda S (2015) Bacterial community shifts associated with high abundance of Rhizobium spp. in potato roots under macronutrient-deficient conditions. Soil Biol Biochem 80:232-236

Van Elsas JD, Heijnen CE (1990) Methods for the introduction of bacteria into soil: a review. Biol Fert Soils 10(2):127-133

Van Nieuwenhove C, Van Holm L, Kulasooriya SA, Vlassak K (2000) Establishment of Azorhizobium caulinodans in the rhizosphere of wetland rice (Oryza sativa L.). Biol Fert Soils 31:143-149

Vance CP (1998) Legume symbiotic nitrogen fixation: Agronomic aspects. In: Spaink HP, Kondorosi A, Hooykaas PJJ (eds) The Rhizobiaceae, molecular biology of model plantassociated bacteria. Kluwer Academic Publishers, Dordrecht, pp 509-530 
Vessey JK (2004) Benefits of inoculating legume crops with rhizobia in the northern Great Plains. Retrieved 2/2005, from http://www.plantmanagementnetwork.org/pub/cm/review/2004/ inoculant/

Vessey JK, Pawlowski K, Bergman B (2004) Root-based $\mathrm{N}_{2}$-fixing symbioses: Legumes, actinorhizal plants, Parasponia sp. and cycads. Plant Soil 266:205-230

Vessey KJ (2003) Plant growth-promoting rhizobacteria as biofertilizers. Plant Soil 255:571-586

Vincent JM (1962) Influence of calcium and magnesium on the growth of Rhizobium. J Gen Microbiol 28:653-663

Vitousek PM, Aber JD, Howarth RW, Likens GE, Matson PA, Schindler DW, Schlesinger WH, Tilman DG (1997) Human alteration of the global nitrogen cycle: sources and consequences. Ecol Appl 7:737-750

Walley F, Clayton G, Gan Y, Lafond G (2004) Performance of rhizobial inoculant formulations in the field. Retrieved 2/2005, from http://www.plantmanagementnetwork.org/pub/cm/ review/2004/inoculant/

Wani PA, Khan MS, Zaidi A (2007) Effect of metal tolerant plant growth promoting Bradyrhizobium sp. (vigna) on growth, symbiosis, seed yield and metal uptake by green gram plants. Chemosphere 70:36-45

Xavier IJ, Holloway G, Leggett M (2004) Development of rhizobial inoculant formulations. Crop Manage 3(1)

Yang J, Kloepper JW, Ryu CM (2009) Rhizosphere bacteria help plants tolerate abiotic stress. Trends Plant Sci 14(1):1-4

Yokoyama T, Ohyama T (2007) Current status and future direction of commercial production and use of bio-fertilizers in Japan. Food and Fertilizer Technology Center (FFTC), Taipei 